electrical devices in connexion with the microphone, it is possible to improve the broadcast voice by smoothing out rough and strengthening weak notes. Sounds sent over the radio can be varied by placing in the broadcasting circuit filters, compensators, and amplifiers so that the frequency and volume are permanently varied or are left to be varied at the discretion of the control engineer. High-pitched voices are transmitted much better than deep voices over the radio. It was suggested that by putting different compensators in various branches of the broadcasting networks it would be possible for a political candidate to talk with the appropriate accent in several States simultaneously.

\section{Standardisation at the Ottawa Conference}

THE question of industrial standardisation will again come before the Imperial Conference when it meets in Ottawa at the end of this month, and Mr. C. le Maistre, director of the British Standards Institution, has been appointed adviser to the delegation from Great Britain on British standards. It will be recalled that at the last two Imperial Conferences very great importance was attached to the development of inter-Empire standardisation, and to the preparation of national industrial specifications by national standardising bodies. In order to fulfil the recommendation of the last Imperial Conference, the British Engineering Standards Association recently widened its scope, and is now known as the British Standards Institution. Since last November, Mr. le Maistre has been touring the Dominions in comnexion with the development of this work.

\section{New Deposits of $\mathrm{T}$ in in the U.S.S.R.}

THE expedition of the Soviet Academy of Science under the direction of Dr. A. E. Fersman has discovered new deposits of tinstone in Tadjikistan, to the north-east of Stalinabad. The Soviet Union so far has not had its own supply of tin ore, the working of the two deposits in Transbaikalia having only just commenced. The discovery of new rich deposits of tinstone is of great importance to the national economy of the U.S.S.R., particularly in the manufacture of tins for preserved foods, in the motor tractor industry, in the production of steam engines, etc.

\section{Announcements}

The Rev. J. P. Rowland, S.J., has been appointed director of the Stonyhurst College Observatory, in succession to the Rev. E. D. O'Connor, S.J., who has been appointed rector of the College.

AT the quarterly meeting of the Royal College of Surgeons held on July 14, Sir H. J. Waring was elected president of the College in succession to Lord Moyniham. The Lister Memorial lecture of the College will be delivered by Sir Charles Ballance on April 5, 1933.

THE following officers have been elected to the Council of the Institution of Electrical Engineers for the year 1932-33, to take office on Sept. 30 :--President, Prof. E. W. Marchant; Vice-President, Mr. H. T. Young; Hon. Treasurer, Mr. P. Rosling ; Ordinary Members of Council, Prof. J. K. Catterson-Smith,
Mr. A. P. M. Fleming, Mr. H. W. H. Richards, and Mr. W. S. Burge.

AT the annual general meeting of the British Association of Research for the Cocoa, Chocolate, Sugar Confectionery, and Jam Trades, which was held on July 5, Mr. J. G. Mathieson was re-elected president and Mr. A. W. Beach and Mr. C. E. Southwell were re-elected vice-presidents.

Ir is announced that by the will of Mr. James M. G. Prophit, a sum of about $£ 120,000$ is to be divided equally for the purposes of cancer and tuberculosis research. The tuberculosis moiety has been allocated to various hospitals and colleges, including the Royal College of Physicians, and to two studentships. The cancer moiety has been allocated chiefly to the Royal College of Surgeons, the Radium Institute, the British Empire Cancer Campaign, and also to two studentships.

The ninth Annual Conference of the Association of Special Libraries and Information Bureaux will be held at Somerville College, Oxford, on Sept. 23-26. The presidential address will be delivered by Sir Charles Sherrington on Sept. 23. Among the papers to be read at the Conference are: "The Relationship between Science and the Humanities ", by Prof. J. L. Myers; "Classified Subject Indexes to Periodical Volumes", by Dr. S. C. Bradford and Prof. A. F. C. Pollard ; and "History and Sources of Official Vital Statistics", by Prof. M. Greenwood. Particulars of the Conference can be obtained from the General Secretary, Association of Special Libraries and Information Bureaux, 16 Russell Square, London, W.C.1.

Messrs. W. Heffer and Sons, Ltd., have issued a catalogue (No. 390) of publishers' 'overstocks', or 'remainders' as they are more generally termed. All books are new and are offered at about half the published price or less. We notice in the section of reference books sets of Millais" "Mammals of Great Britain and Ireland " and Thorburn's "British Mammals".

Applications are invited for the following appointments, on or before the dates mentioned :-A parttime lecturer in the Biology Department at the Plymouth and Devonport Technical College-The Secretary for Education, Education Offices, Rowe Street, Plymouth (July 23). A lecturer in mathematics at the Portsmouth Municipal College-The Registrar (July 29). A resident engineer in the Public Works Department, Hydro-Electric Branch, of the Government of the Punjab-The High Commissioner for India, General Department, India House, Aldwych, London, W.C.2 (Aug. 4). An assistant teacher of mechanical engineering and an assistant teacher in the Nautical College at the Central Technical School, Byrom Street, Liverpool-The Director of Education, 14 Sir Thomas Street, Liverpool (Aug. 8). A fulltime secretary to' the Museums Association-The Secretary, Museums Association, 39в Alfred Place, South Kensington, London (Aug. 10). A junior assistant in the Directorate of Ballistics Research, Research Department, Woolwich, S.E.18.-The Chief Superintendent. A physics laboratory assistant at the Radium Therapy Department, Duke of York Home, Bradford.

$$
\text { No. 3273, VoL. 130] }
$$

